\title{
Pre-eruptive intracoronal resorption on cone beam computed tomography: two case reports
}

\author{
Reabsorção dentinária pré-eruptiva na tomografia de \\ feixe cônico: dois relatos de caso
}

\author{
Monikelly do Carmo Chagas NASCIMENTO' ${ }^{1}$ iD 0000-0001-6765-0428 \\ Camila de Oliveira NATIVIDADE ${ }^{1}$ iD 0000-0003-0026-5597 \\ Eduardo Zambaldi CRUZ1 ${ }^{1}$ iD 0000-0002-5019-2210 \\ José Luiz Cintra JUNQUEIRA' ID 0000-0001-6788-4021
}

\section{ABSTRACT}

Pre-eruptive intracoronal resorption (PIR) is a rare lesion that occurs within the dentin of the crown on unerupted teeth. The aim of this article is to report two rare cases of a PIR in impacted canine using cone beam computed tomography (CBCT). High resolution CBCT images (Prexion 3D) were indicated for evaluating of the non-erupted tooth, claiming no other related signs or previous history to be considered. In the first case, the images revealed an impacted and mesioinclined superior canine. In the coronary portion, it was observed an irregular hypodense lesion, involving the dentin, enamel tissue, and communication with the external surface of the tooth. In the second case, the images showed an impacted superior canine in the vertical position. It also revealed a hypodense lesion with poorly defined limits envolving the dentin, which extends over the crown. In both cases, the tooth was not in contact with the adjacent lateral tooth. Therefore, PIR in impacted teeth is rare, which is frequently diagnosed through routine radiographs. Additionally, CBCT seems to be an invaluable tool for providing accurate information about the exact topography, relationships with adjacent structures, helping, therefore, on the appropriate treatment planning.

Indexing terms: Cone beam computed tomography. Diagnosis. Tooth resorption

\section{RESUMO}

A reabsorção intra-coronária pré-eruptiva $(R I P)$ é uma alteração rara que ocorre na coroa de dentes não erupcionados. O objetivo desse trabalho é documentar dois casos raros de RIP em caninos inclusos nas imagens de tomografia computadorizada de feixe cônico (TCFC). As imagens de TCFC de alta resolução (Prexion 3D) foram solicitadas cuja indicação era avaliação topográfica de dente não irrompido alegando nenhuma outra causa relacionada ou história pregressa a ser considerada. Caso 1: As imagens apresentaram o dente 23 incluso e mesioangulado. Na porção coronária observa-se imagens hipodensas irregulares abrangendo o tecido dentinário, esmalte e comunicação com a superfície externa do dente. Caso 2: As imagens apresentaram o dente 13 incluso em posição vertical. Imagem hipodensa e de limites pouco definidos, que se estende por quase toda coroa e acomete principalmente a dentina. Ambos os casos não apresentavam íntimo contato com o dente lateral adjacente. Portanto, pode concluir, que a reabsorção coronária de

\footnotetext{
$\boldsymbol{\nabla} \boldsymbol{\nabla} \boldsymbol{v}$

1 Faculdade São Leopoldo Mandic, Instituto de Pesquisas São Leopoldo Mandic, Radiologia. Rua José Rocha Junqueira, 13, Swift, 13045-755, Campinas, SP, Brasil. Correspondência para / Correspondence to: MCC NASCIMENTO. E-mail: <monikellyccn@gmail.com>.

$\boldsymbol{\nabla} \boldsymbol{\nabla} \boldsymbol{v}$

How to cite this article

Nascimento MCC, Natividade CO, Cruz EZ, Junqueira JLC. Pre-eruptive intracoronal resorption on cone beam computed tomography: two case reports. RGO, Rev Gaúch Odontol. 2019;67:e20190048. http://dx.doi.org/10.1590/1981-8637201900048
} 
dentes totalmente inclusos é um achado raro de etiologia desconhecida, onde a TCFC é um instrumento de grande valia para fornecer informações da exata topografia, relações com estruturas adjacentes, e auxílio para o correto planejamento do tratamento. Portanto, RIP em dentes impactados é raro, o que é frequentemente diagnosticado através de radiografias de rotina. Além disso, CBCT parece ser uma ferramenta inestimável para fornecer informações precisas sobre a topografia exata, relações com estruturas adjacentes, ajudando, portanto, no planejamento do tratamento adequado.

Termos de indexação: Diagnóstico. Reabsorção de dente. Tomografia computadorizada de feixe cônico.

\section{INTRODUCTION}

Pre-eruptive intracoronal radiolucency (PIR) are often located within the dentin, adjacent to the dentin-enamel junction. in the occlusal aspect of the crown. As the lesions resemble caries, they are often referred as "pre-eruptive caries". However, this alteration cannot be considered a caries lesion since these developing teeth are encased in its crypt and is not likely to have been infected with cariogenic microorganisms [1].

The pathogenesis of PIR is unclear. However, some studies have already reported relation with local factors. Ectopic eruption of the affected tooth or adjacent teeth in contact may cause local pressure and stimulate resorptive cells to induce dentin resorption. This alteration seems to have a strong association with decayed or endodontically treated primary teeth $[2,3]$.

The prevalence of PIR varies from 2 to $15 \%$, depending on the diagnostic imaging method used. Most cases of PIR can be observed in the mixed dentition, especially in the mandible in the first premolars and in teeth with delay eruption. The clinical diagnosis in early stage is now primaly based on diagnosis from radiography. However, in children, this is not usually carried out during routine dental examination [4-6].

Radiographically, the PIR presents a radiolucent image and well defined limits into the crown. It may extend to the entire dentin, and in rarer cases, to the enamel and pulp. This factor emphasizes the importance of an early diagnosis to obtain a better dental prognosis. Although the recommended treatment is surgical intervention to prevent the progression of the lesion to the pulp, some studies suggest that shallower lesions could be monitored until eruption to be treated thereafter $[4,7,8]$.

Compared to radiography, cone beam computed tomography (CBCT) images can be useful for diagnosing PIR because it provides an accurate representation of internal dental anatomy. The prevalence of intracoronal resorption using $\mathrm{CBCT}$ has been much higher than that recorded previously using panoramic or bitewing radiographs $[9,10]$. After approval by the local research ethics committee (protocol number 3.405.909), this article reports two cases of PIR on CBCT images.

\section{CASE REPORTS}

\section{CASE 1}

A 40-year-old male patient was referred to an orthodontic dental clinic with a chief complaint of aesthetics reasons. Clinically, the absence of the upper left canine in the oral cavity was observed. The patient reported no history of trauma or major complications associated with the possible absence of the tooth. A CBCT examination of the tooth was requested to perform the treatment planning. The images were scanned with the CBCT unit Prexion 3D (Teracom, San Mateo, CA) operating at 90kvp and 4mA with a voxel size of $0.1 \mathrm{~mm}$, a field of view (FOV) of $51 \mathrm{x}$ $51 \mathrm{~mm}$, and using high resolution protocol. The images revealed an impacted and mesioinclined upper left canine (23), located above teeth 22, 24 and 25. The root was impacted and mesioinclined (figure 1 e 2 ) In the coronary portion, it was observed an irregular hypodense lesion, involving the dentin, enamel tissue, and communication with the external surface of the tooth.

Considering the images performed for this protocol, the 23 showed a preserved periodontal ligament space and absence of contact with the roots of the adjacent teeth.

\section{CASE 2}

A 36-year-old woman was referred by a general dentist to Dep. Orthodontics. The patient's concern was mainly related to the esthetic improvement. The 


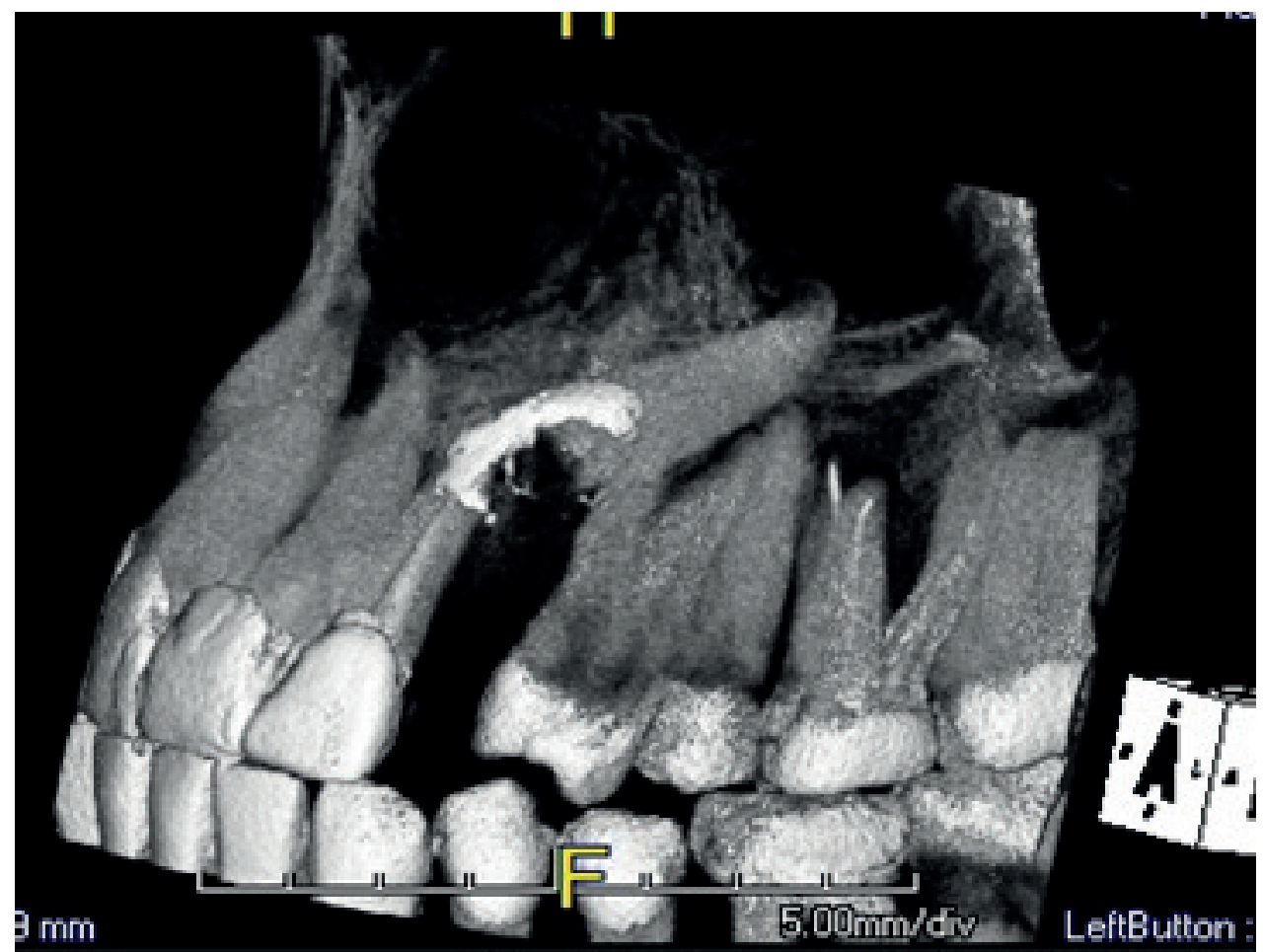

Figure 1. Three-dimensional image showing the spatial positioning of the tooth 23.

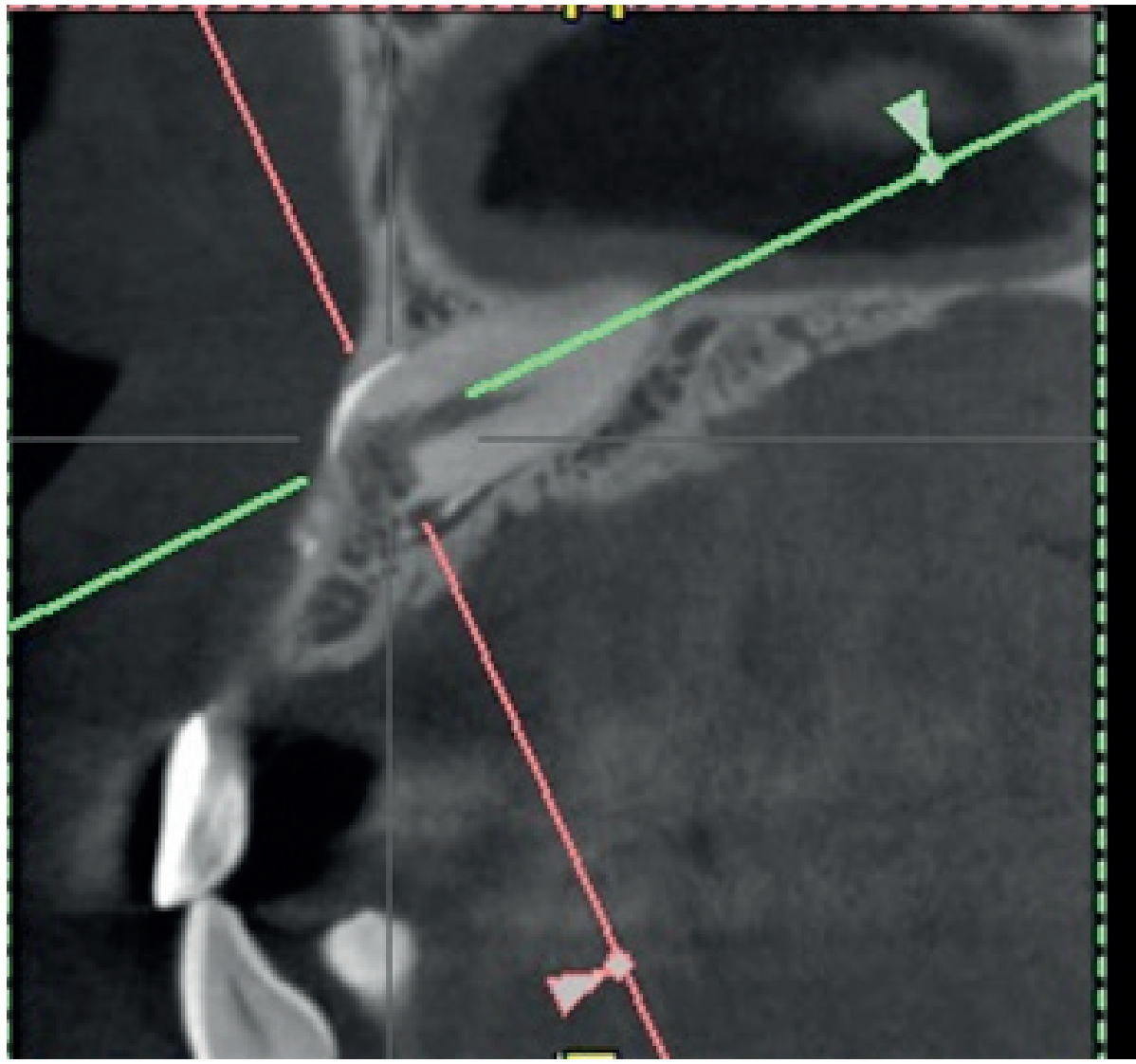

Figure 2. Sagittal section showing the coronary resorption. 


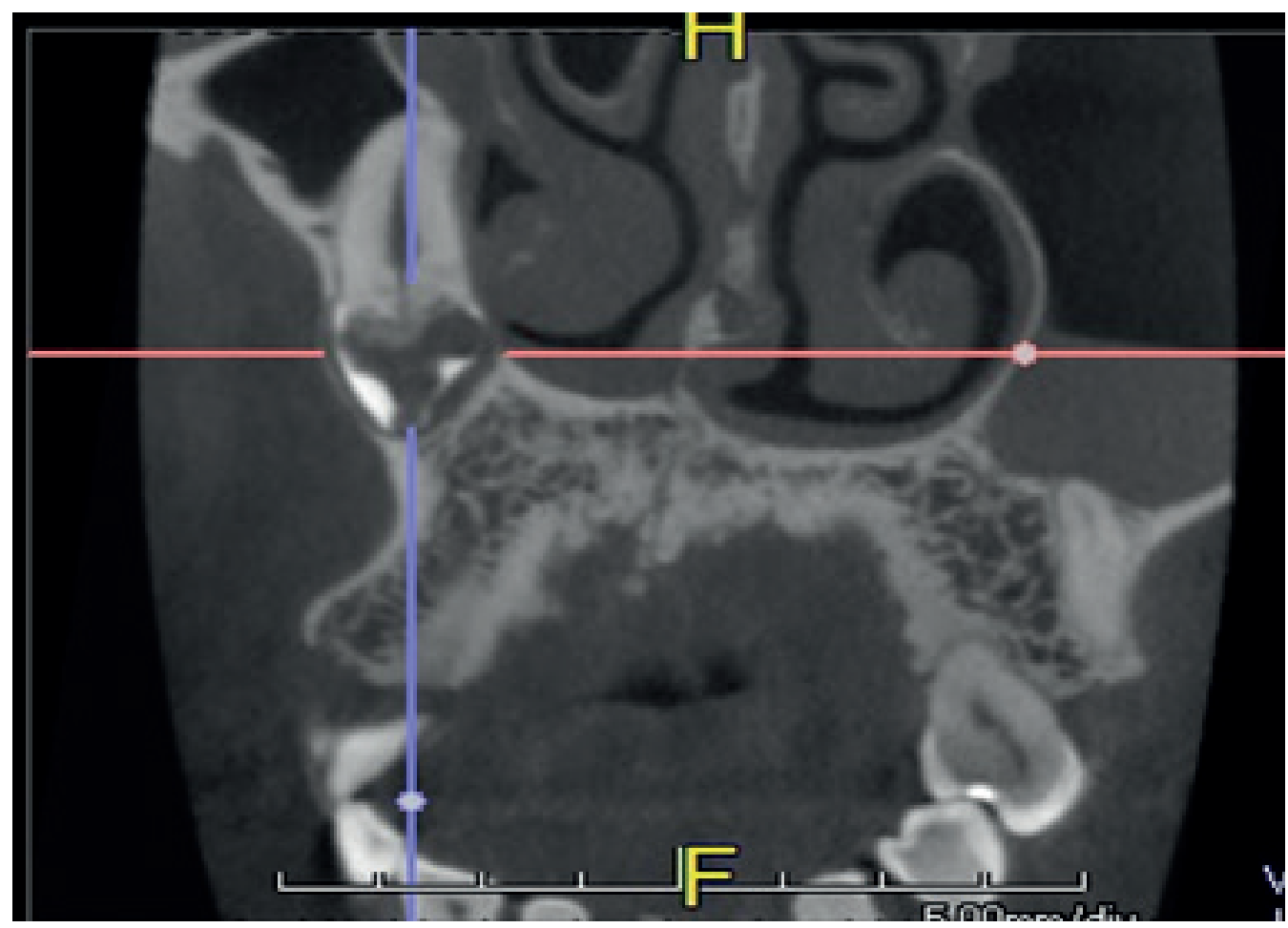

Figure 3. Coronal section showing the spatial positioning of tooth 13 and the dentin and enamel resorption located in the crown region.

radiographic examination revealed impaction of the superior right canine (13). A CBCT examination of the tooth was requested to perform the treatment planning. The images were scanned with the CBCT unit Prexion 3D (Teracom, San Mateo, CA) operating at 90kvp and $4 \mathrm{~mA}$ with a voxel size of $0.1 \mathrm{~mm}$, a field of view (FOV) of $51 \mathrm{x}$ $51 \mathrm{~mm}$, and using high resolution protocol.

The images showed tooth 13 in vertical position, above the tooth 53, and absence of contact with adjacent teeth. The root was located below the floor of the maxillary sinus and in contact with the lateral wall of the nasal fossa. Hypodense and poorly delimited images involving almost the entire crown of the tooth 13 were observed. It was also observed the preserved periodontal ligament space (figure 3).

\section{FINAL CONSIDERATIONS}

The two cases reported are unusual incidental radiographic findings that should be taken into consideration due to the fragility of the tooth in the coronary portion. Although, its frequency has increased because of the use of CBCT images. Clinician must investigate every permanent tooth in a pre-eruptive stage to detect this kind of resorption. CBCT images can help to identify on the diagnosis and severity of PIR. Surgical traction, as part of orthodontic treatment, should be studied based on previous cases reported in the literature [11].

\section{CONCLUSION}

PIR of fully impacted teeth is a rare finding, where the $C B C T$ exam is an important tool for providing accurate topography information, relationships with adjacent structures, and aid in treatment planning.

\section{Collaborators}

MCC NASCIMENTO, substantial contributions to draft the manuscript. CO NATIVIDADE, substantial contributions to the final approval of the version to be published. EZ CRUZ, substantial contributions to the final critical revision of the manuscript. JLC JUNQUEIRA, substantial contributions to the final critical revision of the manuscript.

\section{REFERENCES}

1. Davidovich E, Kreiner B, Peretz B. Treatment of severe pre-eruptive intracoronal resorption of a permanent second molar. Pediatr Dent. 2005;27:74-77. 
2. Al-Batayneh OA. Aljamal GA. Pre-eruptive intracoronal dentine radiolucencies in the permanent dentition of jordanian children. Eur Arch Dent. 2014; 15: 229-236. http:// dx.doi.org/10.1007/s40368-013-0104-x

3. De Souza N, Vaz A, Chalakkal P. Intracoronal radiolucency in an unerupted premolar: a rare occurrence. J Clin Diagn Res. 2017 Jan; 11(1):ZD04-05. http://dx.doi.org/10.7860/ JCDR/2017/22791.9135

4. Ari T. Management of "hidden caries": a case of severe pre-eruptive intracoronal resorption. J Can Dent Assoc. 2014:80:e59.

5. Al-Tuwirqi A, Seow WK. A controlled study of pre-eruptive intracoronal resorption and dental development. J Clin Pediatr Dent. 2017; 41(5):374-380. http://dx.doi.org/10.17796/1053-4 628-41.5.374

6. Zilberman U, Milevski I, Yegorov D, Smith P. A 3000 year old case of an unusual dental lesion: pre-eruptive intracoronal resorption. Arch Oral Biol. 2019; 97: 97-101. http://dx.doi. org/10.1016/j.archoralbio.2018.10.015

7. Czarnecki G, Morrow M, Peters M, Hu J. Pre eruptive intracoronal resorption of a permanent first molar. J Dent Child (Chic). 2014;81(3):151-5.
8. Iha MC, Kramer PF, Ferreira SH, Ruschel HC. Pre-eruptive intracoronal radiolucency in first permanent molar. Int J Clin Pediatr Dent. 2018; 11(2): 151-54. http://dx.doi.org/10.5005/ jp-journals-10005-1502

9. Demirtas O, Ertas ET, Dane A, Kalabalik F, Sozen. Evaluation of pre-eruptive intracoronal resorption on cone-beam computed tomography: a retrospective study. Scanning. 2016;38:442-7. http://dx.doi.org/10.1002/sca.21294

10. Demirtas O, Dane A, Yildirim E. A comparison of the use of cone-beam computed tomography and panoramic radiography in the assessment of pre-eruptive intracoronal resorption. Acta Odontol Scand. 2016; 74(8): 636-4. http:// dx.doi.org/10.1080/00016357.2016.1235227

11. Lenzi R, Marceliano-Alves MF, Alves F, Pires FR, Fidel S. Pre-eruptive intracoronal resorption in a third upper molar: clinical, tomographic and histological analysis. Aust Dent J. 2017; 62(2): 223-7. http://dx.doi.org/10.1111/adj.124

Received on: 19/6/2019

Final version resubmitted on: 8/8/2019

Approved on: 15/8/2019 